\title{
Facility Location Model for Emergency Humanitarian Logistics Using Set Covering and Analytic Network Process (ANP) Method
}

\author{
Prafajar Suksessanno Muttaqin, Rizki Afif Finata, and Ami Ayu Masturo \\ Department of Industrial and System Engineering, Universitas Telkom, Bandung \\ e-mail: prafajar37@gmail.com
}

\begin{abstract}
This research will conduct set covering problem and analytical network process in determining the location of the swab test due to the outbreak of corona virus infection disease 2019 (Covid-19) in Bandung. The location of the swab test can also function as a location for fulfilling medical aids to the residents around the affected area. Solving the solution is done by developing a mathematical model consisting of numbers 1 and 0 in the form of integer linear programming with an output that is zero-one. The objective function is to minimize number of swab test location. From the results, it was found that the location of the swab test was chosen so that it could fulfill the affected areas in Bandung City. Furthermore, using the analytical network process approach, it is obtained 5 criteria, which are then weighted for each criterion, so the calculation results show that area Cicendo is a priority for the location of swab test.
\end{abstract}

Keywords-Facility Location, Humanitarian Logistics, Swab Test.

\section{INTRODUCTION}

$\mathrm{C}$ ORONA virus infection disease pandemic, 2019, or (Covid-19) is beginning of coronavirus disease spread throughout the world. This disease caused by a new type of coronavirus named SARS-CoV-2. This outbreak was first detected in Wuhan City, Hubei Province, China in December 2019 and by the World Health Organization as a pandemic on March 11, 2020. Covid-19 in Indonesia initially occurred at the beginning march 2019 and continues to increase until it becomes 31.186 positive cases as of 7 June 2020 spread in 32 of 34 provinces in Indonesia.

Humanitarian logistics is an activity that includes planning, implementation and control of cost of flow and storage of goods efficiently and effectively from the point of origin to point of consumption with the aim of reducing the increasing number of disasters victims and very vulnerable pandemics [1]. It can also be interpreted briefly about the processes and systems needed to mobilize people, resources, skills and knowledge as well as insights in helping victims of a disaster. Humanitarian logistics (disaster logistics) itself is basically part of the study of logistics management and supply chain management. However, there are some fundamental differences between the two including, unexpected demand in the period, geographical location, type and amount of commodity, processing time in this case lead time tends to be short, and the risks faced [2].

This research will conduct an analysis of the location of the swab test location due to the outbreak of Covid-19 in the city of Bandung using the method of set covering and analytic network process (ANP). In determining the location, it also includes fulfilling medical aid to the residents around the affected area. Set covering problem (SCP) is a combinatorial problem that is modeled in the form of integer linear programming. In this method can be used to determine how many facilities are needed and where the location of these facilities can reach a certain area. Wibowo conducted a model to determine the location of the bus rapid transit (BRT) stop in the Rajabasa-Sukaraja corridor in the city of Bandar Lampuung using the set covering model [3]. In addition the set covering problem and analytic network process (ANP) method for the allocation of tankers in Indonesia's eastern sea [4]. The model in several studies is used to weight criteria, updated the Multi Criteria Decision Making (MCDM) method, changing the opinion of the use of the AHP method deemed less relevant. ANP is defined as a non-parametric non-parametric qualitative approach to the decision making process with a general framework without making assumptions. The advantage of ANP over AHP is that ANP is superior in terms of simplicity, connectivity, comparative objective, more accurate predictions, more stable and robust results.

\section{RESEARCH METHODOLOGY}

Research methodology is explain the steps being taken in conducting research to fit the purpose of research. The research method is divided into several stages including problem identification, data collection and processing, results and discussion, conclusions and suggestions.

Problem identification begins with observation and monitoring through an information system regarding Covid-19 in West Java Province. Based on actual data it can be identified that Bandung City is one of the cities / regencies that has the most positive patients in West Java. The number of people in supervision or ODP is one of the bases for conducting rapid tests. This is because basically there are more people in supervision who do not report or do not know that the person is experiencing these symptoms, so it is necessary to do a rapid test, in order to minimize the occurrence of additional people under supervision even patients in treatment. But in determining the location of the rapid/swab test required optimal planning. Thus, if the addition of positive patients in the future, it is expected that research results can provide benefits and solve the problem. 
The 8th International Conference on Transportation \& Logistics (T-LOG 2020)

Surabaya September 6th-7th 2020, Universitas Internasional Semen Indonesia (UISI), Gresik, Indonesia

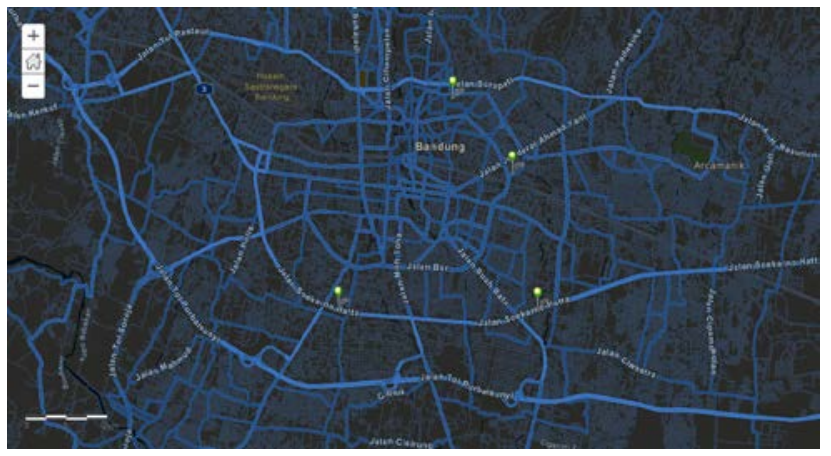

Figure 1. Location Map of Swab Test in Bandung City.

In the data collection and processing stage begins with collecting data both primary and secondary data including several locations that are recommended to do swab test, criteria used for swab test locations, sub-district data up to villages that have patient patients under surveillance, both patient and patient with positive corona virus infection disease 2019 (Covid-19). At this stage the data processing is done by calculating set covering to classify the classification of covering between locations and then weighting each criterion using the ANP method, as a basis for decision making for site selection using the multi criteria decision making method.

Result and discussion stages are more focused on a more complete explanation of the results of data processing in the previous stage, namely the location chosen for swab tests that can serve the surrounding area. At the conclusion and suggestion stages, conclusions are made that answer the research objectives as well as suggestions that can be done for further realization and research.

\section{DATA COLLECTION AND PROCESSING}

\section{A. Data Collection}

After identification of the problem, then performed data collection related to research. Some data needed to perform data processing such as location data that is recommended for swab tests, criteria used for swab test locations, sub-districts and village's data that have people under surveillance (ODP), patients under surveillance (PDP), and patients with positive Covid-19.

\section{1) Actual Location of Swab Test}

Based on interviews conducted with relevant parties regarding the location of swab test in Bandung, it was further identified that there are currently 4 locations for swab test implementation, in the form of longitude and latitude coordinates, namely in Sate Building (-6.902439, 107.618810), Transportation Office (-6.946395, 107.593361), Fire and Disaster Management Office (-6.916776, 107.634124), Ministry of Religion Office (-6.947312, 107.636884). The Figure 1 shows location map of swab test in Bandung City.

As shown in Figure 1, it can be seen that there are only 4 locations for swab test. Meanwhile, if we do a benchmark from several other countries, one of steps taken in reducing amount of covid transmission will require massive rapid and swab test to the community. In this case, it is necessary to determine the optimal number of locations to conduct a swab test in Bandung City.

2) Site Selection Criteria and Indicator

Decision makers define criteria as a measure, rules, and
Table 1.

Criteria and Indicators in Site Selection

\begin{tabular}{|c|c|c|}
\hline No & Criteria & Indicator \\
\hline 1 & Transportation Aspect & $\begin{array}{l}\text { Accessibility } \\
\text { Distance }\end{array}$ \\
\hline 2 & $\begin{array}{l}\text { Infastructure Support } \\
\text { Aspect }\end{array}$ & $\begin{array}{l}\text { Availability of electricity } \\
\text { network } \\
\text { Availability of Water } \\
\text { Availability of } \\
\text { Telecommunications }\end{array}$ \\
\hline 3 & $\begin{array}{l}\text { Socioeconomics } \\
\text { Aspect }\end{array}$ & Crime Rate \\
\hline 4 & Environment Aspect & $\begin{array}{l}\text { Availability of Employee } \\
\text { Flood Prone }\end{array}$ \\
\hline
\end{tabular}

standards that are used as a reference in determining the solution of the problem. Various factors and criteria are considered in the decision making process to determine which is the most appropriate location. The criteria used in this study are a reference from several related studies and refer to regulations of Head of the National Disaster Management Agency (BNPB) No. 3 of 2014 concerning instructions for carrying out operational equipment warehouses for disaster management. The Table 1 is criteria and indicators in site selection of swab test. From Table 1, there are 4 criteria that used in decision making for determining the location of swab test of covid disease.

3) ODP, PDP and Positive Covid-19 Location Distribution

Based on corona virus prevention and control guidelines, the ministry of health of the republic of indonesia, people and or patients are divided into several levels. ODP is an acronym of people under surveillance A person is included in the ODP category if he is traveling to another country which is the center of spread of the corona virus. Someone also includes ODP if they have direct contact with a patient who is positively affected by corona. People who included into this group are those who have not shown symptoms of illness. The second category is PDP which is an acronym of patients under surveillance. People who included into this category have been treated by health workers (become patients) and show symptoms of illness such as fever, cough, rheum (runny nose) and dyspnea (shortness of breath). Another category is OTG, which is someone who is asymptomatic and has a risk of contracting from people confirmed Covid-19. Asymptomatic people (OTG) are in close contact with Covid-19 confirmed cases. In this case OTG and ODP are made into one category because they have same contact and are in same location. On the other hand, patients infected with Covid-19 are patients who have a positive test through a polymerase chain reaction (PCR). The Figure 2 below shows Map of Covid-19 Based on District in Bandung City

As shown in Figure 2, it can be seen that there are map that shows spread of Covid-19 in Bandung City Based on District. The map contain information about Covid-19 which are colored differently each district. The Covid-19 Map of Bandung City was developed using ESRI (Environmental Systems Research Institute) as an international vendor of geographic information system (GIS) software, web GIS and geodatabase management applications.

\section{B. Data Processing}

\section{1) Set Covering Model}

This research using Set Covering Problem (SCP) with deterministic model. Deterministic model used is different from probabilistic model, because in this model it can be 
The 8th International Conference on Transportation \& Logistics (T-LOG 2020)

Surabaya September 6th-7th 2020, Universitas Internasional Semen Indonesia (UISI), Gresik, Indonesia

$\begin{array}{lll}\text { Global optimal solution found at iteration: } 0 \\ \text { Objective values: } 10.754 \\ \text { Variable } & \text { Value } & \text { Reduced Cost } \\ \text { X1 } & 1.000000 & 1.000000 \\ \text { X2 } & 0.000000 & 1.000000 \\ \text { X3 } & 0.000000 & 1.000000 \\ \text { X4 } & 1.000000 & 1.000000 \\ \text { X5 } & 1.000000 & 1.000000 \\ \text { X6 } & 1.000000 & 1.000000 \\ \text { X7 } & 0.000000 & 1.000000 \\ \text { X8 } & 1.000000 & 1.000000 \\ \text { X9 } & 0.000000 & 1.000000 \\ \text { X10 } & 0.000000 & 1.000000 \\ \text { X11 } & 0.000000 & 1.000000 \\ \text { X12 } & 1.000000 & 1.000000 \\ \text { X13 } & 0.000000 & 1.000000 \\ \text { X14 } & 0.000000 & 1.000000 \\ \text { X15 } & 0.000000 & 1.000000 \\ \text { X16 } & 1.000000 & 1.000000 \\ \text { X17 } & 0.000000 & 1.000000 \\ \text { X18 } & 0.000000 & 1.000000 \\ \text { X19 } & 0.000000 & 1.000000 \\ \text { X20 } & 1.000000 & 1.000000 \\ \text { X21 } & 0.000000 & 1.000000 \\ \text { X22 } & 1.000000 & 1.000000 \\ \text { X23 } & 1.000000 & 1.000000 \\ \text { X24 } & 1.000000 & 1.000000 \\ \text { X25 } & 0.000000 & 1.000000 \\ \text { X26 } & 0.000000 & 1.000000 \\ \text { X27 } & 0.000000 & 1.000000 \\ \text { X28 } & 0.000000 & 1.000000 \\ \text { X29 } & 0.000000 & 1.000000 \\ \text { X30 } & 0.000000 & 1.000000 \\ \text { X10 } & & \end{array}$

Figure 3. Output of Problem Using Lingo 17.0.

known with certainty of demand to do a swab test, whereas probabilistic model is uncertain. To be able to fulfill the swab test tool request, an additional allowance for the swab test tool request is added. The model used in this research is also specific to a single product and allocation of products is one echelon as research [5]. Mathematical formulation in SCP model in this research is as follows.

Minimize $Z=\sum_{j}\left(x_{j}+\frac{1}{h} x_{j}\right)$ For $j=1,2,3, \ldots, n$

$x_{j}$ : Candidate location of swab test (district)

$h$ : demand each location swab test

The objective function (1) is to minimize number of swab test location to be built in Bandung. Based on problem there are 30 alternative location which is generalized from districts Bandung. District location Data of Bandung was obtained from interview and Central Bureau of Statistics. Numerical experiments using data and model simulation with LINGO 17.0 software is as follows:

$\left.x_{1}+\frac{1}{146106} x_{1}\right)+\left(x_{2}+\frac{1}{153417} x_{2}\right)+\ldots \ldots .+\left(x_{30}+\frac{1}{61916} x_{30}\right)$

The value for each $\mathrm{xj}$ is 0 or 1 . This means that if the value of $x j=0$ then location candidate is not selected / built. If the value of $x j=1$ then location candidate is chosen / built. Constraint for the model used is that each demand can be fulfilled by at least 1 location. Mathematical model of this statement is as follows:

$\sum_{i=\mathbb{V} i} x_{j} \geq 1 \quad \forall i$

In this problem of this research, demand from location candidate (X1) can only be fulfilled by the location candidate 1 (X1). Whereas the location candidate 2 can be fulfilled by location candidates 2 and 3, so the equation model is $\mathrm{X} 2+\mathrm{X} 3 \geq 1$. For demand from location 3 can be fulfilled by location candidate 2 and 3 , so the equation model is $\mathrm{X} 2+\mathrm{X} 3 \geq 1$. For each location, for example location 1 to location 30 is made mathematical model constraint for each demand.

For several candidate location were always be selected as swab test location such as location 4 (X4) that represent Transportation office in Bojongloa Kidul district, location 8
Table 2.

The location of the swab test chosen

\begin{tabular}{lll}
\hline \hline No. & Code & Location \\
\hline 1 & X1 & Bandung Kulon \\
2 & X4 & Bojongloa Kidul \\
3 & X5 & Astana Anyar \\
4 & X6 & Regol \\
5 & X8 & Bandung Kidul \\
6 & X12 & Cibiru \\
7 & X16 & Arcamanik \\
8 & X20 & Batununggal \\
9 & X22 & Andir \\
10 & X23 & Cicendo \\
11 & X24 & Bandung Wetan \\
\hline \hline
\end{tabular}

Table 3.

Selected Swab Test Location if $p=7$

\begin{tabular}{lll}
\hline \hline No. & \multicolumn{1}{c}{ Location } & \multicolumn{1}{c}{ Reach Location } \\
\hline 1 & Bandung Kulon (X1) & Babakan Ciparay (X2) \\
& & Bojongloa Kaler (X3) \\
2 & Bojongloa Kidul (X4) & Astana Anyar (X5) \\
& Regol (X6) \\
& & Buah Batu (X9) \\
3 & Bandung Kidul (X8) & Rancasari (X10) \\
& & Lengkong (X7) \\
4 & Batununggal (X20) & Antapani (X17) \\
& & Kiaracondong (X19) \\
& & Andir (X22) \\
5 & Cicendo (X23) & Sukajadi (X28) \\
& & Sukasari (X29) \\
& & Sumur Bandung (X21) \\
& & Cibeunying Kaler (X26) \\
6 & Bandung Wetan (X24) & Coblong (X27) \\
& & Cidadap (X30) \\
& & Ujung Berung (X14) \\
& & Cibiru (X12) \\
& & Panyileukan (X13) \\
7 & Arcamanik (X16) & Gedebage (X11) \\
& & Mandalajati (X18) \\
& & Cinambo (X15) \\
\hline \hline
\end{tabular}

(X8) that represent Ministry of Religion Affairs in Bandung Kidul District, location 20 (X20) that represent Fire and Disaster Management Office in Batununggal district, and location candidate 24 (X24) that represent Sate Building in Bandung Wetan district. Solution to the problem with Branch and Bound in Lingo 17.0 software produced a solution as shown in Figure 1.

From the results of optimization with the mathematical model above, the swab location test results are obtained. The location of the swab test chosen to be selected can be seen in Table 2.

Max Covering Problem modeling analysis aims to determine the location of the swab tests to be selected when there are restrictions on number of swab test locations to be selected. The results of calculations using Set Covering Problem (SCP) shows that number of locations selected to fulfill all demand points is 11 location. Because of optimal swab test location is 11 , an alternative sensitivity test is tried when Bandung city government can only add 3 locations. from the current chosen location as explained in the previous section. Selected Swab Test Location if $p=7$ can be seen in Table 3.

From Table 3, we create a map that shows location and their spread based on output in Lingo 17.0 software. The Figure 4 shows selected swab test location map if $p=7$.

Results of proposed swab test locations in Figure 4 then serve as input for the calculation of ANP to determine priority of which location is chosen first to serve as the swab test location in Bandung City. 
The 8th International Conference on Transportation \& Logistics (T-LOG 2020)

Surabaya September 6th-7th 2020, Universitas Internasional Semen Indonesia (UISI), Gresik, Indonesia

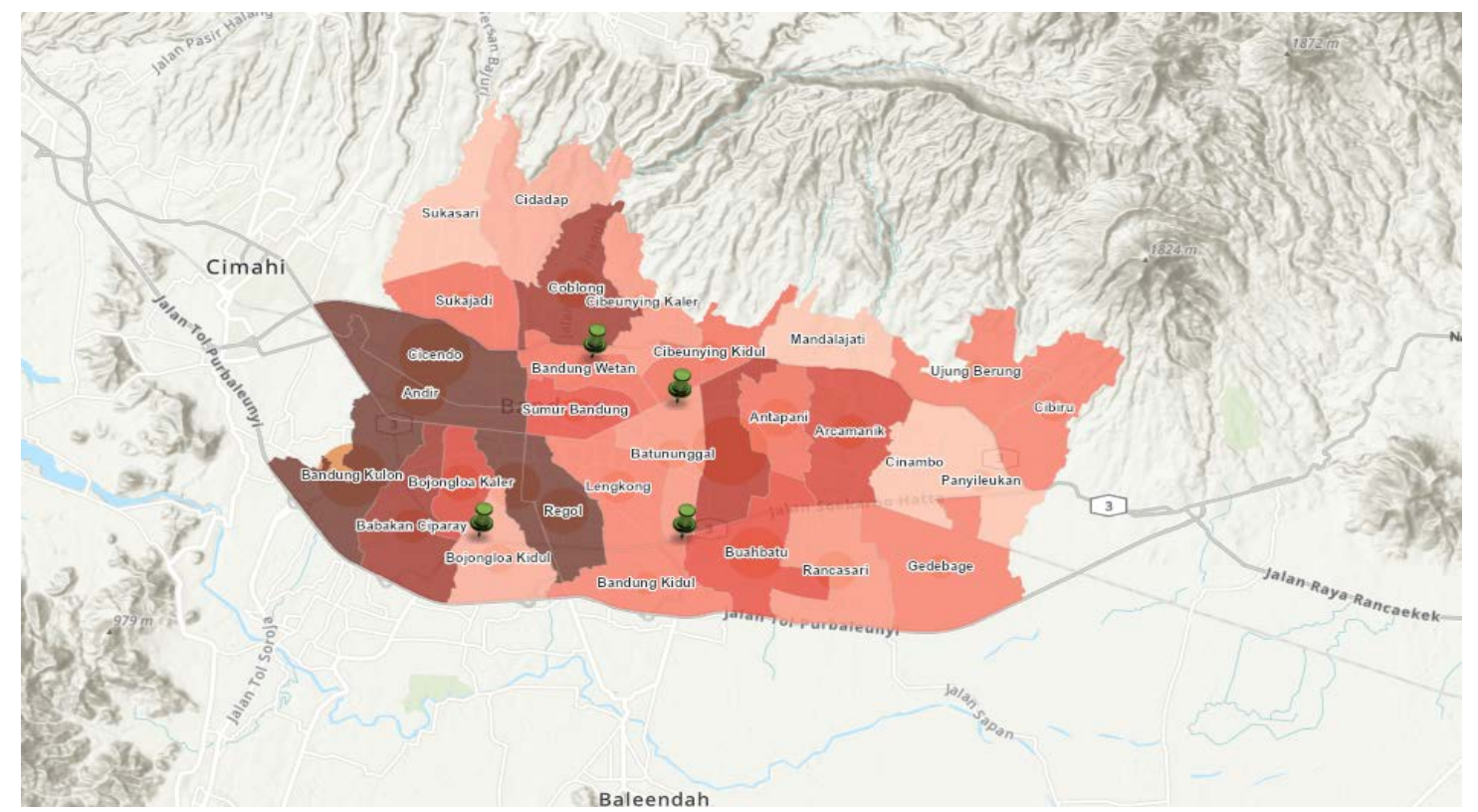

Figure 2. Map of Covid-19 Based on District in Bandung City.

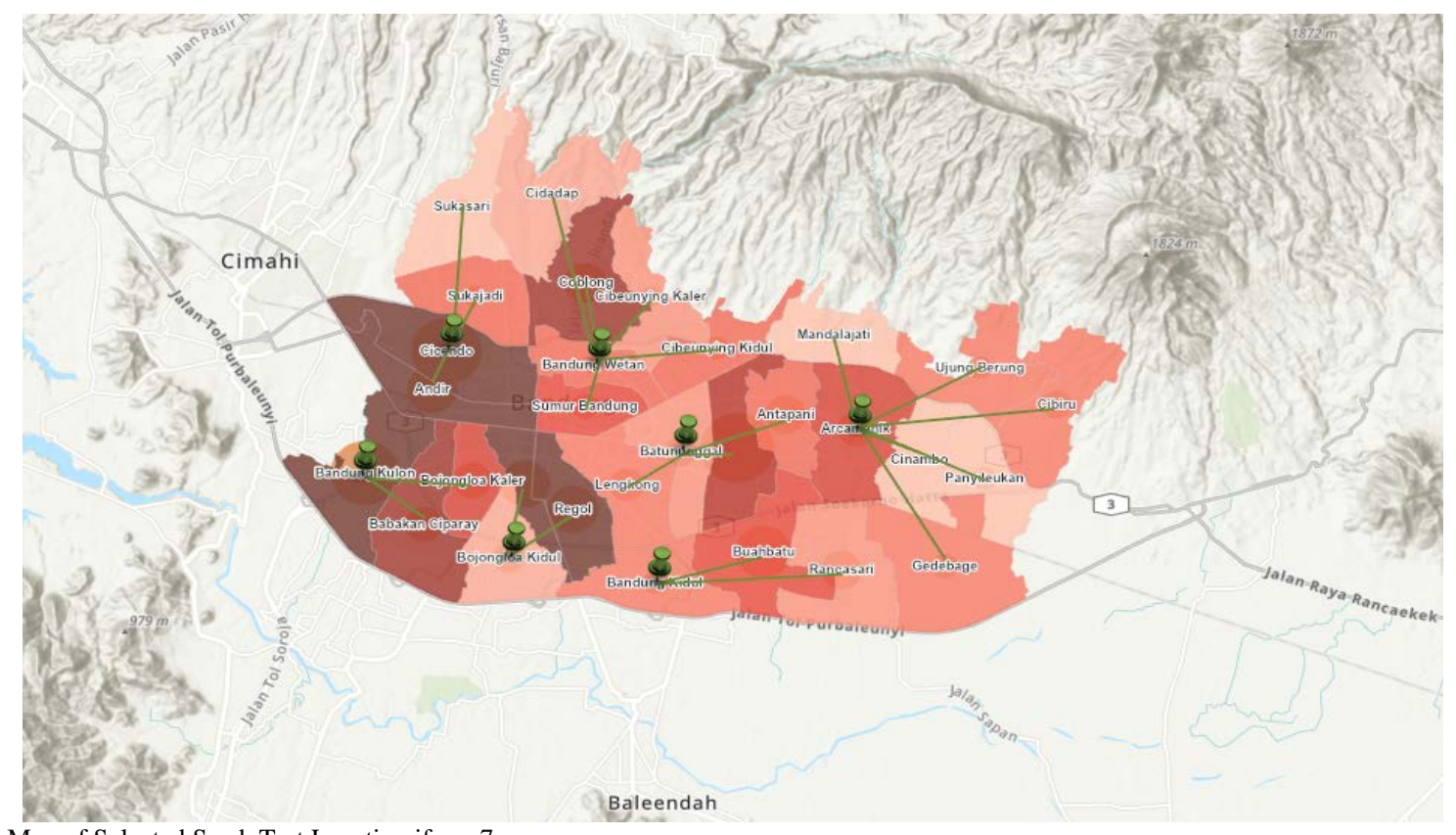

Figure 4. Map of Selected Swab Test Location if $p=7$.

\section{2) Analytic Network Process}

ANP method used to process data begins with creating a network that is appropriate to the problem using super decisions V3.2 software. This is done to calculate how much weight for each indicator in the selection process and alternatives in determining the location of the Swab Test in Bandung. Figure 5 shows the model of the problem using the super decisions V3.2 software.

In Figure 5 it can be seen that the model consists of three levels, namely the level of objectives to be achieved, the level of criteria, and alternative levels. Furthermore, at each node is calculated by entering the value of the pairwise matrix comparison in accordance with the relationship relationship on the network. The value of the paired matrix in this study was obtained from the expert judgment. Furthermore, the preparation of the ANP questionnaire uses the relationship between the criteria. The questions in the questionnaire are pairwise comparisons between criteria and between alternatives regarding the selection of swab test locations.
Data obtained from 5 respondents were leveled by the geometric mean process with the formula:

$$
\sqrt[5]{\prod_{i=1}^{5} X_{1}}
$$

$X_{i}$ : decision on comparison of criteria- $i$

The results of leveling are then entered into a pairwise comparison in Super Decisions V3.2 software. Then the data is entered into the available pairwise comparison matrix, the following is the matrix column display to enter the total results of the questionnaire. Each time after entering the pairwise comparison values for each node, the local priority weight is calculated. It aims to determine the weight of each interconnected element and the consistency ratio value. The ratio of consistency for each comparison must be smaller than 0.1. If the overall pairwise comparison of all nodes is consistent (consistency ratio below 0.1), weights will be obtained for each alternative swab test location. 


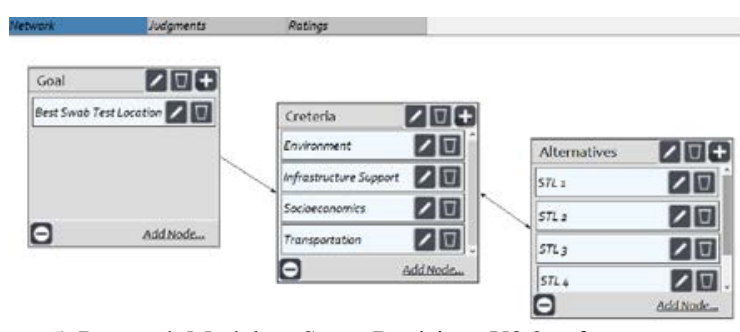

Figure 5. Research Model on Super Decisions V3.2 software.

\section{RESULT AND FUTURE RESEARCH}

\section{A. Result}

The results of sensitivity analysis by changing the priority weights to choose priority locations, then Cicendo (X23) becomes first, Bandung Kulon (X1) becomes second, Arcamanik becomes third (X16). After validating with expert judgment, it turns out the results of this research are in accordance with direction of Mayor of Bandung City, which states that location of swab test should be prioritized in districts that have highest number of positive patients. Based on Covid-19 Bandung Information Center (covid19.bandung.go.id) two of district that have highest number of positive patients are Cicendo and Bandung Kulon. Based on the results of data processing, data analysis and discussion, further conclusions can be drawn and suggestions for further research are as follows.

1) The results of calculations using Set Covering Problem (SCP) shows that number of locations selected to fulfill all demand points is 11 location namely Bandung Kulon (X1), Bojongloa Kidul (X4), Astana Anyar Kidul (X5), Regol (X6), Bandung Kidul (X8), Cibiru (X12), Batununggal (X20), Andir (X22), Cicendo (X23), Bandung Wetan (X24), Coblong (X27). However, if Bandung City Government can only choose 3 location from 4 location that already exist ( $\mathrm{p}=$ 7 ), so the 3 location are Bandung Kulon (X1), Arcamanik (X16), and Cicendo (X23).

2) The results of sensitivity analysis by changing the priority weights to choose priority locations, then Cicendo (X23) becomes first, Bandung Kulon (X1) becomes second, Arcamanik becomes third (X16). After validating with expert judgment, it turns out the results of this research are in accordance with direction of Mayor of Bandung City, which states that location of swab test should be prioritized in districts that have highest number of positive patients. Based on Covid-19 Bandung Information Center (covid19.bandung.go.id) two of district that have highest number of positive patients are Cicendo and Bandung Kulon.

\section{B. Future Research}

1. The model generated from this research can be used as a reference for Bandung City Disaster Management Agency (BPBD) in selecting and determining the location of the swab test with the condition that the criteria to be used are the same as this research.

2. For further research, a wider case study can be used as an example within the scope of province.

3. For further research can use a broader case study as an example within the scope of the province with a case study on the most significant provinces affected Covid-19.

4. Research criteria can be added and adapted based on case and with regard to the model formulation.

5. For further research can use other method such as Adaptive Neuro Fuzzy Inference System (ANFIS) and use other criteria to produce more precise and accurate solutions.

\section{REFERENCES}

[1] A. Thomas and L. Kopczak, "From Logistics to Supply Chain Management: The Path Forward in the Humanitarian Sector.," 2005.

[2] B. Balcik and B. Beamon, "Facility location in humanitarian relief. International Journal of Logistics-research and Applications,” Int $J$ Logist-Res Appl, 2008.

[3] H. Wibowo, M. Anggraini, and R. Aldino, "Pemodelan set covering problem dalam penentuan lokasi halte Bus Rapid Transit ( BRT ) Pada Koridor Rajabasa-Sukaraja di Kota Bandar Lampung," Spektrum Ind., vol. 16, no. 2, pp. 111-225, 2018.

[4] A. Susanto, A. D. Susanto, and O. S. Suharyo, "Optimization Of The Anp And Set Covering Method For The Allocation Of Tanker In The East Sea Region Of Indonesia,” vol. 9, no. 2, pp. 63-74, 2018.

[5] D. Priyanggo, U. Ciptomulyono, and P. Suwarno, "Analisis Penempatan Gudang Bantuan Omsp Tanggap Darurat Bencana Alam Menggunakan Set Covering Dan ANP (Studi Kasis di Kabupaten Cilacap)," in Prosising Seminar Nasional Pascasarjana STTAL, 2016. 